\title{
PAPERS TO APPEAR
}

Olnes, J., Citta, J.J., Quakenbush, L., George, C., Harwood, L., Lea, E., and Heide-Jørgensen, M.P. Use of the Alaskan Beaufort Sea by Bowhead Whales (Balaena mysticetus) Tagged with Satellite Transmitters, 2006-2018.

Wilson, A., Levkoe, C.Z., Andrée, P., Skinner, K., Spring, A., Wesche, S., and Galloway, T. Strengthening Sustainable Northern Food Systems: Federal Policy Constraints and Potential Opportunities.

Ollier, M., Giles, A.R., Etter, M., Ruttan, J., Elanik, N., Goose, R., and Ipana, E. Promoting a Culturally Safe Evaluation of an On-the-land Wellness Program in the Inuvialuit Settlement Region.

Bongelli, E., Dowsley, M., Velasco-Herrera, V.M., and Taylor, M. Do North American Migratory Barrenground Caribou Subpopulations Cycle?

Mosurska, A., and Ford, J.D. Unpacking Community Participation in Research: A Systematic Literature Review of Community-based and Participatory Research in Alaska.

Ross, P., and Mason, C.W. "We Hardly have any Moose Around here Anymore": Climate Change and the Barriers to Food Security in the Dehcho Region, Northwest Territories.

Loring, P.A., Tang, C., and Beaudreau, A.H. Stability During Times of Change: Subsistence Portfolios in Mid20th Century Rural Alaska.

Tsuji, L.J.S., and General, Z. Akimiski Island, Nunavut, Canada: The Use of Cree Oral History and Sea-level Retrodiction to Resolve Aboriginal Title.

Segal, R.A., Scharien, R.K., Duerden, F., and Tam, C.-L. The Best of Both Worlds-Connecting Remote Sensing and Arctic Communities for Safe Sea Ice Travel. 